\title{
What Might have been the Ancestor of New World Siskins?
}

\author{
Antonio Arnaiz-Villena*, Valentin Ruiz-del-Valle, Raquel Reguera, Pablo Gomez-Prieto and \\ Juan Ignacio Serrano-Vela
}

Department of Immunology, University Complutense and The Madrid Regional Blood Center, Madrid, Spain

\begin{abstract}
Eurasian Carduelis spinus (siskin) has given rise to the C.pinus (pine siskin) North American radiation,which includes C.dominicensis, C.p. perplexus and C.atriceps .

It is addressed the question why C.spinus is not thriving now in America.
\end{abstract}

\section{INTRODUCTION}

The Eurasian Siskin (Carduelis spinus) appeared on Earth in the Pliocene Epoch about five million years ago (MYA) [1,2]. It is the one extant direct ancestor of several North American finches (see Fig. 1 inset), which appeared after 2 MYA [1,2], which are named as follows:

1). Carduelis dominicensis, the Antillean Siskin from the Caribbean high peaks of La Hispaniola Island.

2). Carduelis pinus pinus, the Pine Siskin from North America.

3). Carduelis pinus perplexus, the Pine Siskin from Guatemalan altiplano.

4). Carduelis atriceps, the Black-capped Siskin from Guatemalan altiplano.

\section{RESULTS \& DISCUSSION}

Nowadays, the Eurasian Siskin does not thrive in America, but in easternmost and westernmost Eurasia, having a gap between Central Russia and its easternmost range. The most important feature of the Eurasian Siskin is that it is a migratory bird whose North to South migrations do not always follow the same longitudinal patterns ("irruptive") [3]. It is feasible that Carduelis spinus was thriving in Eurasia and also in North America around the Pliocene / Pleistocene Epoch limit, about 2 MYA. Soon after this time, the first glaciation covered North America with a kilometric thick ice shield [4]. The Eurasian Siskin might have taken refuge in ice-free Caribbean Islands and in Mexican Mountains and Guatemalan-Mexican altiplano. Its Summer-Winter and North-South migrations would have been disrupted because it became isolated in all-year relatively warm temperature (Caribbean); year-round relatively and quite stable low temperature (Guatemalan-Mexican altiplano) and relatively temperature stable Mexican Mountains. The Eurasian Siskin could have first given rise to the endemic Antillean Siskin

*Address correspondence to this author a the Departamento de Inmunologia, Facultad de Medicina, Universidad Complutense de Madrid, Avenida Complutense s/n, 28040 Madrird, Spain; Tel: +34 91301 7354; Fax: +34 91301 7213; E-mail: aarnaiz@med.ucm.es
(Carduelis dominicensis) at the Caribbean high peaks of La Hispaniola Island soon after 2 MYA (Fig. 1) [5]. Afterward, about 200,000 years ago, the Eurasian Siskin might have given rise to the Pine Siskin Carduelis pinus pinus in the non-glaciated Mexican Sierras [4]; at about the same time (200,000 years ago), the Black-capped Siskin (Carduelis atriceps) and the Pine Siskin Carduelis pinus perplexus might have appeared in the non-glaciated GuatemalanMexican altiplano [4]. Rainfall variations in the Caribbean during the Pleistocene, however, could have also affected the distribution of these birds [6]

This would be a typical example of adaptive radiation caused by a North to South migration barrier (First North American Ice Shield Glaciation) and provincialism that drove evolution to create these new finches species. When last Wisconsin Glaciation ended and North American ice melted about 12,000 years ago, Carduelis pinus would have followed the ancestral North to South migrations and covered all North America, occupying the American niches that the Eurasian Siskin couldn't reach from Asia during the last 2 million years because of the extant thick ice shield; neither could it afterwards because of species competition by ecologic niche with its descent Carduelis pinus. This evolutionary theory for the finch group appearance is schematic. More complicated events may have occurred during the Nebraskan, Kansan, Illinoan and Wisconsin North American glaciations, and / or their respective interglacial periods (Aftonian, Yarmouth and Sangamon) [4], and other explanations may also be possible, see [7].

\section{ACKNOWLEDGEMENTS}

This work was supported in part by three grants from the Fundación Mutua Madrileña (2004, 2005, 2006), and from the Ministry of Health (FIS, PI05/1039) and the Ministry of Foreign Affairs (AECI) grants.

\section{REFERENCES}

[1] Helm-Bychowski KM, Wilson AC. Rates of nuclear DNA evolution in pheasant-like birds: evidence from restriction maps. Proc Natl Acad Sci USA 1986; 83: 688-92.

[2] Arnaiz-Villena A, Ruiz-del-Valle V, Moscoso J, Serrano-Vela JI, Zamora J. mtDNA phylogeny of North American Carduelis pinus group. Ardeola 2007; 54: 1-14. 


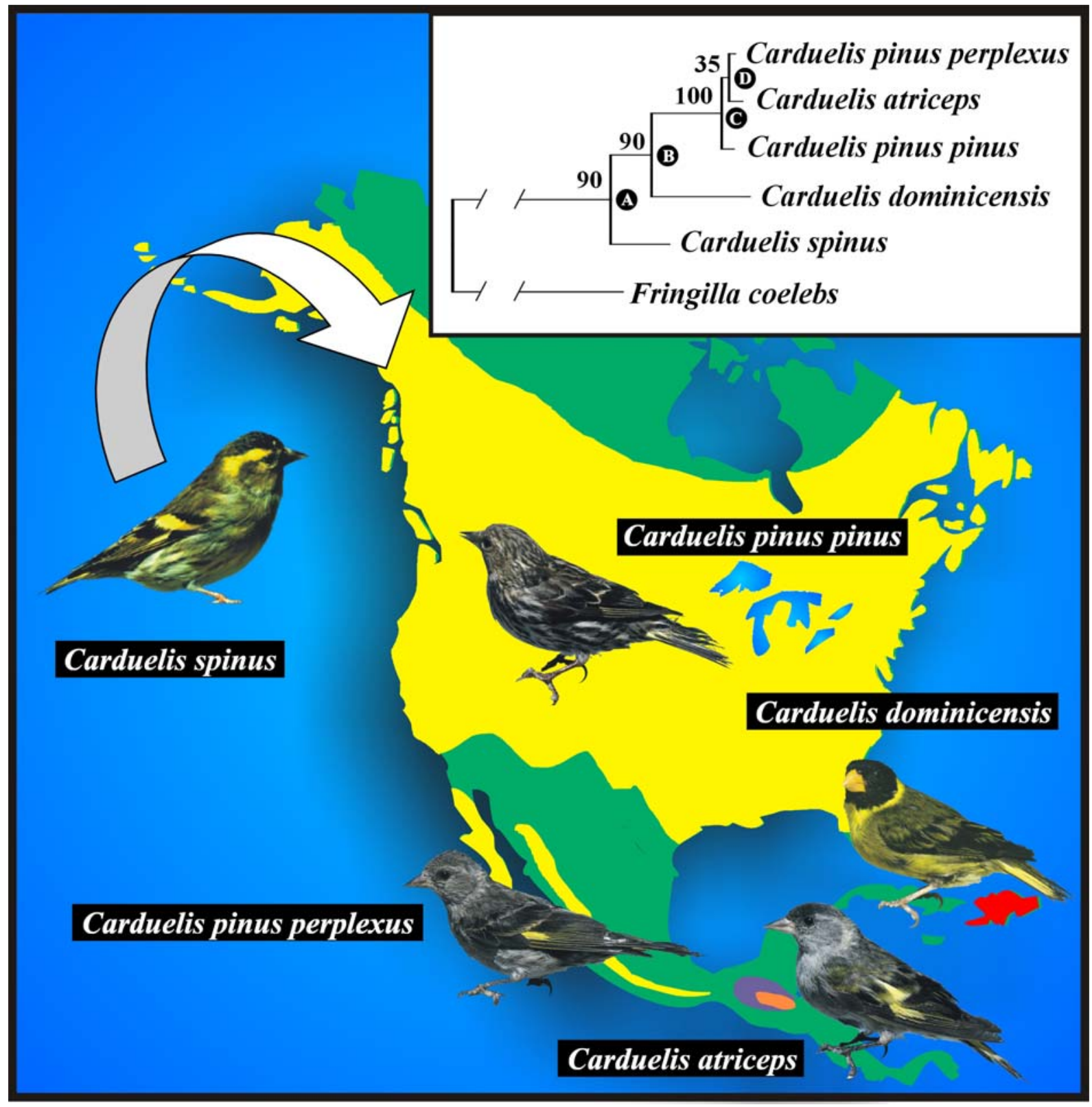

Fig. (1). The Eurasian Siskin (Carduelis spinus) possibly thrived in North America before two million years ago when glaciations started. The ice shield on North America could have driven speciation by provincialism of 'daughter species' isolated in the Caribbean Mountains (C. dominicensis), in Mexican Sierras (C. p. pinus) and in Mexican-Guatemalan altiplano (C. p. perplexus and C. atriceps). See also ref. [2]. Present day ranges: $C$. p. pinus in yellow; $C$. dominicensis in red; $C$. atriceps in orange; $C$. p. perplexus in purple. Inset represents a Bayesian Inference dendrogram based on mitochondrial cytochrome b DNA sequences. Note that the nodes are strongly supported, like in previous works [2] which used other methodologies.

[3] Clement P, Harris P, Davies J. Finches and Sparrows. London: Croom Helm 1993.

[4] Brown JM, Lomodino MV. Biogeography. Sunderland: Sinauer Associates 1998.

[5] Filardi CE, Moyle RG. Single origin of a pan-Pacific bird group and upstream colonization of Australasia. Nature 2005; 438: 216-9.
[6] Pregill GK, Olson SL. Zoogeography of West Indian vertebrates in relation to Pleistocene climatic cycles. Annu Rev Ecol Syst 1981; 12: 75-98.

[7] Todd WE. A Study of the Neotropical Finches of the Genus Spinus. Ann Carnegie Mus 1926; 17(1): 11-82. 